\title{
An Investigation into the Problem of Human Capital Burnout in the Public Service of Zimbabwe: A Case of Secondary School Teachers in Marondera District, Mashonaland East Province.
}

\author{
${ }^{1}$ Kepekepe, M., ${ }^{2}$ Bhebhe, T.B., ${ }^{3}$ Karedza, G. \\ ${ }^{1,2,3}$ Chinhoyi University of Technology
}

\begin{abstract}
This study used both the qualitative and the quantitative research approaches in which the standardised Maslach Burnout Inventory (MBI) questionnaire was used to collect data from respondents to measure the dimensions and prevalence of burnout. A sample of eighty-eight secondary school teachers in MaronderaDistrict was used. This was followed by face-to-face interviews which targeted five secondary school heads. The findings of the study indicated that a significant number of teachers experienced different levels of burnout ranging from moderate to high burnout. The research showed that the socio-demographic factors as well as gender, marital status and age were associated with the nature and level of burnout which secondary school teachers succumb to unknowingly in their career. This caused symptoms such as fatigue, stress, emotional imbalance, desire to leave the job for greener pastures, loneliness and general lack of enthusiasm, dislike of the job, poor performance,fanned illnesses and absenteeism to be prevalent among affected teachers. The findings also showed that poor reward system, work overload, lack of resources, lack of recognition, lack of awareness on the appropriate burnout coping strategies, lack of stress management skills, poor motivation techniques, inappropriate leadership styles and unfavourable work environment were some of the drivers of burnout among teachers. The study recommended training of educational managers and leaders such as school heads, heads of departments, inspectorsand education officers about the implications of burnout, its signs and symptoms, control, management and eradication strategies. Use of ICTs in teaching to reduce work overload, recreational facilities in schools, reduction of teacher pupil ratios, improvement of conditions of service such as leaves and remuneration were also recommended. The study also recommended that authorities should engage in burnout policy formulation, implementation, monitoring and evaluation aimed at managing burnout as a way to rejuvenate the teaching profession where many teachers are suffering unknowingly to a level that students continue to benefit less.
\end{abstract}

Keywords: burnout, MBI, emotional exhaustion, depersonalisation, personal accomplishment

\section{Introduction}

The burnout phenomenon is a worldwide occurrence that has shaken organizations and individuals who aim to reap the fruits of their investments in business. Human capital has been noted in recent studies to be the key driver to the success and growth of any organization. If the 'fire that burns inside' any human capital (the desire to work hard and be productive) burns out, the employer ceases to benefit just as there is no benefit from a candle that has burnt out. The study of human factor burnout among educationists especially teachers in the Public Service of Zimbabwe has been an area overlooked by researchers. The study sought to fill this gap in knowledge.

It is a truism that the most valuable wealth for any country is its human capital of all ages especially those in the economically active working category who are employed to drive various sectors of the economy. Human capital is wealth which creates wealth. Humans are far much more valuable than machines because it is only humans that can think, negotiate deals, understand clients, make decisions and seize opportunities that bring wealth to the organisation; but when that human capital is affected by burnout, they cease to be of value. According to Hewitt (2014), engaged employees deliver greater productivity, better customer service, superior quality products and service and more innovative solutions. This is contrary to employees that are disengaged who cost organizations.

\subsection{Meaning of burnout}

David Ballard, a psychologist with the American Psychological Association defines job burnout as an extended period of time where someone experiences exhaustion and a lack of interest in work-related activities, resulting in a decline in their job performance (http //www.forbes.com/sites) - [accessed 20 September 2016]. Ballard (2015) goes further to state that burnout manifests itself in different forms; exhaustion, lack of motivation, cognitive problems, frustration, emotional imbalance, poor anger management, chronic stress, poor job performance, poor deportment, withdrawal, poor workplace relationships and health problems to mention 
but just a few. Burnout reduces a worker's labour contribution to a level where they become virtually useless to the organisation. If not checked and corrected, burnout leads to devastating results including decline in profits, decline in customer base or even closure of the organisation. It reduces the net worth of an individual worker and affects the productivity levels of the whole company. Maslach and Jackson (1986) defined burnout as a syndrome of emotional exhaustion, depersonalisation and reduced personal accomplishment that occurs among individuals who do people work of some kind. Maslach and Jackson (1986) linked burnout to job turnover, absenteeism, low morale and other dysfunctions such as exhaustion, insomnia and many more. Burnout is a state of emotional, mental, and physical exhaustion caused by excessive and prolonged stress. It occurs when one feels overwhelmed and unable to meet constant work demands. As the stress continues, one begins to lose the interest or motivation that led them to take on a certain role in the first place. Burnout has expanded internationally and has led to conceptual models that are aimed at addressing the impact on the phenomenon in organizations.

\subsection{Background to the problem}

Human capital burnout is a phenomenon that has taken a centre stage in organizations especially in the Public Service in Zimbabwe where the media constantly reports about poor performance, fatigue, absenteeism, long queues, poor clients care and laziness among civil servants in schools, local government, police, colleges, hospitals and other public offices. It is not uncommon to hear reports of public officers dozing in offices, shouting at clients and neglecting or ignoring clients while long queues await to be served.Burnout has also manifested itself among teachers with the public outcry pointing to outright poor performance, laziness, dislike of work and lack of creativity with some teachers teaching theway they were taught many years ago or using the same notes given to them when they were students. The victims have often been the thousands of students across the country who endure the pain of travelling to school daily to meet an unimaginative, passive, tired and unprepared teacher. In this way, thousands of intelligent students who would have otherwise enjoyed a great future to change their lives and improve Zimbabwe have had their dreams shattered and failure rates in some schools continue to increase. There has been no intention to understand why the situation continues to deteriorate with school heads and other education officers resorting to force, threats, demotions, suspensions and dismissals as a way of dealing with the culprits who invariably need help because dealing with the symptoms will not correct the problem. According to scholars, researchers and industrial psychologists, many such employees could be succumbing to burnout and the only way to curb it is to go to the root of it and seek to understand its causes first.

\subsection{Statement of the problem}

Human capital burnout in the Public Service has resulted in low productivity, disengagement and failure to meet organizational and national goals (Flett and Hewitt: 2006).Burnout has been linked to impersonal and uncaring attitudes towards clients (Cloninger, 1996:433). In this respect civil servants manifest burnout tendencies through reduced service delivery, impatience, dozing off at work, disengagement, indiscipline, poor work output, intolerance, lack of enthusiasm, absenteeism, slowdown in performance and health problems such as hypertension among other signs and symptoms. The bottom line being that a worker with burnout ceases to be productive and the employer and clients become the greatest losers. While burnout has become a widely recognised problem affecting service delivery the world over, there have been no studies to see how it manifests in the education sector with specific reference to secondary schools in Zimbabwe which are critical in shaping the future of the youths and the nation. This study sought to investigate the prevalence and causes of burnout among secondary school teachers, and proffer solutions which if adopted could assist in rejuvenating public servants to restore their enthusiasm for work.

\subsection{Research objectives}

The main objective for the study was to investigate human capital burnout among employees in the civil service with particular reference to teachers in secondary schools. The following are some of the research objectives:

1. To investigate the prevalence of burnout among secondary school teachers.

2. To assess the appropriateness of motivation techniques used on teachers in secondary schools.

3. To investigate the effects of work overload and poor conditions of service on burnout in the teaching profession.

4. To evaluate the adequacy of coping and stress management strategies used by teachers in secondary schools.

\subsection{Hypotheses}

H1 There is a relationship between poor motivation techniques and the manifestation of burnout among teachers. 
H2Socio-demographic factors such as gender, age, marital status and level of educational attainment Areassociated with burnout among secondary school teachers in Zimbabwe.

H3Nature of work especially the aspect of too much routine and lack of job enrichment strategies are are associated with prevalenceof burnout among teachers.

\section{Literature Review}

Literature points to the fact that the term 'burnout' was first coined by Freudenberger (1974) who defined the phenomenon as "the extinction of motivation especially where one's devotion to cause a relationship fails to produce the desired results." A study by Schaufeli, Leiter and Maslach (2008) noted that job burnout emerged as an important concept in the 1970s. They postulated that while burnout is a global phenomenon, the meaning of the concept differs from country to country. Christian and Tonder (2009) traced the origins of burnout and found out that in some countries such as Sweden, it is treated as an illness requiring medical attention which transcends to psychiatric diagnosis while in other countries it is treated as a non-medical problem. There are also other countries which treat burnout as a social problem worth of attention and amelioration.

\subsection{Causes of burnout}

Researchers such as Maslach (2008) carried out studies and concluded that burnout often stems from the job. Workers who are overworked and undervalued are at risk of burnout. Hardworking office workers who have not had vacation leave in years are equally at risk although burnout can also affect housewives who are overwhelmed with household work including looking after children (Schaufeli, 2003).Studies by Gholipour (2011) proved that lifestyle and personality traits of an individual can contribute to burnout. Those who overwork and do not spare time for recreation or rest are at risk of burnout.

According to Cordes, Dougherty and Blum (1997),some of the causes of burnout in the workplace include doing monotonous, boring, repetitive or routine-like work. Ibid (1997) went further to state that working in a chaotic environment, not being recognised or rewarded for good work, unclear job descriptions and demanding work which one has little or no control over are some of the drivers of burnout. Smith (2015) notes that one's lifestyle can also contribute to burnout. Overworking in a non-supportive job where there is no room for socialisation is yet another driver of burnout. Having too many responsibilities which are not delegated can also drive burnout. Ibid (2015) noted that not getting enough sleep or rest also causes some people to develop burnout.

Ferreira and Martinez (2012) agree that an individual's personality can also give rise to burnout. For instance, individuals who are reluctant to delegate to others can develop burnout as much as those who are too overzealous in wanting to achieve. Those personalities who are power-hungry and are too eager to be in control as well as those who have a pessimistic view of themselves are prone to burnout.

\subsection{Signsand symptoms of burnout}

Sichambo, Maragia and Simiyu (2012) noted that the problem with burnout is that many people suffer from it unknowingly. An individual suffering from burnout can be identified by detachment and loneliness. $\mathrm{He} / \mathrm{she}$ feels helpless, trapped and defeated. The individual feels tired and drained and is often negative about almost everything at work. He/she is engulfed by a sense of failure and lack of self-worth and may develop frequent headaches, muscle pain, lack of sleep and loss of appetite. Employees suffering from burnout may turndown responsibilities and can take longer to have things done. They feel frustrated and can isolate themselves from others. Such employees may resort to over-indulgence in drugs or alcohol and often absent themselves from work, they fan illness or they may report late for work and dismiss early.

Most researchers note that people often confuse stress forburnout (Sichambo et al, 2012). In an attempt to differentiate stress and burnout,Sichambo et al (2012)differentiated the two as follows:

\begin{tabular}{|l|l|}
\hline Stress & Burnout \\
\hline Affected individual loses energy to pursue tasks & $\begin{array}{l}\text { Affected individual loses of motivation, ideals and hope. He/ } \\
\text { she exhibits prolonged exhaustion. }\end{array}$ \\
\hline Affected individual produces urgency and hyperactivity & Affected individual feels helpless and hopeless \\
\hline Affected individual is characterized by over-engagement & Affected individual is disengaged \\
\hline Primary damage of stress is physical & Primary damage of burnout is emotional \\
\hline Stress leads to anxiety disorders & Burnout leads to detachment and depression \\
\hline $\begin{array}{l}\text { Stress is driven by too many pressures that demand too } \\
\text { much from a worker physically and psychologically }\end{array}$ & $\begin{array}{l}\text { Burnout is driven by lack. (lack of motivation, lack of } \\
\text { appreciation, lack of sleep, lack of success, lack of hopeetc) }\end{array}$ \\
\hline $\begin{array}{l}\text { Stress may cause death tothe affected individual } \\
\text { prematurely }\end{array}$ & $\begin{array}{l}\text { Burnout may cause the victim to feel empty and beyond } \\
\text { caringand to view life as not worth living }\end{array}$ \\
\hline
\end{tabular}

Source: Stress and Burnout in Ministry 


\subsection{Conceptual Framework}

After extensive literature search, this study recommended the conceptual framework below:

\section{Independent variables}

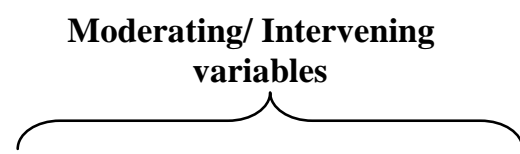

Dependent variable

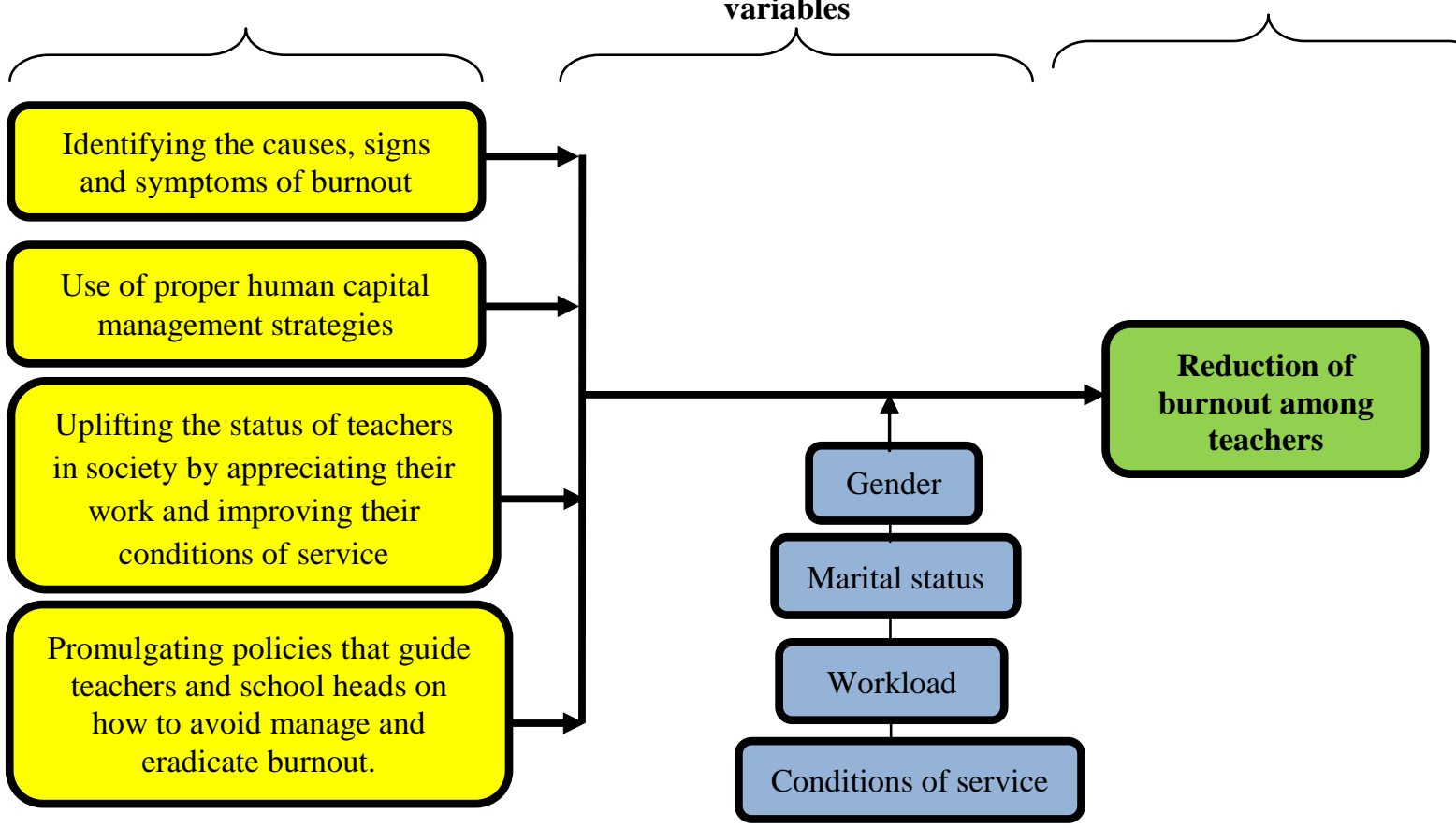

The conceptual framework above could be simplified as follows: The first step in addressing burnout among secondary school teachers would be to carry out a study to ascertain the independent variables of the problem including the causes, current levels of burnout, signs and symptoms because we can only cure what we know. This is in line with Goodhart's Law which states that, 'If you want to solve a problem, it is best to get to the root of it' (Sloman, 2006:552).Training to help teachers and school heads on how to identify, manage and control burnout as well as prevention and coping strategies should be carried out. These can be legitimised by promulgating policies on the same. Proper human capital management practices by educational managers and leaders should be made policy and these include but are not limited to use of ICTs in teaching to reduce work overload and infuse excitement, putting recreational facilities in schools, reduction of teacher pupil ratios and improvement of conditions of service such as leaves and remuneration.

\section{Research Methodology}

This was a Scientific Research study. Scientific research was viewed as most suited in understanding the problem. It was also chosen because of its advantages over other forms of research. Sekaran and Bougie (2013:19) contended that 'Scientific Research is purposive, has rigor, testability, replicability, objectivity, generalizability, parsimony, precision and confidence'. However, Brannick and Roche (2011: pxii) warned that 'No particular research method has clear superiority over others. What is important is what the chosen method reveals about the problem'. This study was a mixed research which used both the qualitative and quantitative research paradigms to get a deeper understanding of the burnout phenomenon among public service human capital in secondary schools in Zimbabwe.

\subsection{The Population}

The population for this study was the entire secondary school teaching population in Marondera District which was broken down as follows:

Table 2 below summarises the population under study

\begin{tabular}{|l|l|l|l|}
\hline Name of Secondary School & $\begin{array}{l}\text { Number of qualified } \\
\text { Female Teachers }\end{array}$ & $\begin{array}{l}\text { Number of qualified } \\
\text { Male Teachers }\end{array}$ & $\begin{array}{l}\text { Total inclusive of } \\
\text { the Head }\end{array}$ \\
\hline 1. Cherutombo High School & 40 & 28 & 68 \\
\hline 2. Nagle House High School & 16 & 13 & 29 \\
\hline 3. Nyameni High School & 37 & 25 & 62 \\
\hline 4. Chitepo Secondary School & 18 & 17 & 35 \\
\hline
\end{tabular}


An Investigation into the Problem of Human Capital Burnout in the Public Service of Zimbabwe:...

\begin{tabular}{|l|l|l|l|}
\hline 5. Marondera High School & 25 & 22 & 47 \\
\hline 6. Rakodzi High School & 31 & 21 & 52 \\
\hline THE POPULATION & $\mathbf{1 6 7}$ & $\mathbf{1 2 6}$ & $\mathbf{2 9 3}$ \\
\hline
\end{tabular}

The Table above shows that the 6 secondary schools in Marondera District have a population of 289 teachersmade up of 167 females and 126 males.

\subsection{The sample}

Bryman (2011) defines a sample as a group of units selected from the population from which information will be collected. This is also alluded to by Akuezelo (1990) who defines a sample as a portion of the population selected for the study. This study settled for the Raosoft Sample Size Calculator which is obtainable on http://www.raosoft.com/ samplesize.html. The Raosoft Sample size calculator states that for a population of 293 at $\pm 5 \%$ margin of error and $95 \%$ confidence level assuming a response rate of $90 \%$, the computed sample size was $\mathbf{9 5}$. This was found to be adequate for this study as it met the requirements of a representative sample as outlined by Saunders, Lewis, and Thornhill (2009).

\subsection{Research instruments}

Research instruments are tools for gathering both primary and secondary data (Sanders et al., 2009). This study used the self-completing questionnaire derived from the standardised Maslach Burnout Inventory (MBI) for the qualified teachers and interviews for the heads of the 6 secondary schools in the district to measure theprevalence of the burnout phenomenon (http://connectability.ca/Garage/wp).The MBI was chosen for the simple reason that it is an internationally recognized tried and tested instrument for measuring the dimensions and prevalence of burnout in human capital.The MBI categorizes the burnout phenomenon into three general scales which are emotional exhaustion, depersonalization and personal accomplishment. All the three are measured separately to determine the nature of burnout that one experiences at work.

\subsection{Response rate}

\section{The Findings}

Out of 95 questionnaires distributed to respondents, 88 were completed and returned thereby achieving a response rate of $93 \%$. The response rate is by all intents and purposes good. Such an interpretation is supported by most authorities in research among them Bell and Bryman (2003), Babbie (2001) and Brannick and Roche (2011) who describe as good any response rate above 50\%.

\subsection{Gender of respondents}

\begin{tabular}{|l|l|l|l|l|l|}
\hline & & Frequency & Percent & Valid Percent & Cumulative Percent \\
\hline Valid & Male & 35 & 39.8 & 39.8 & 39.8 \\
\cline { 2 - 6 } & Female & 53 & 60.2 & 60.2 & 100.0 \\
\hline & Total & $\mathbf{8 8}$ & $\mathbf{1 0 0 . 0}$ & $\mathbf{1 0 0 . 0}$ & \\
\hline
\end{tabular}

The above table shows that there were 35 males and 53 females among the respondents. Males made up $39.8 \%$ while females made up $60.2 \%$ of the respondents. There was a significant bias towards females and this was attributed to the general gender disparity that exists among the urban and peri-urban secondary school teaching population. According to Annual Reports and provincial statistics of the Ministry of Primary and Secondary Education, female teachers transfer from remote schools to urban and peri-urban schools in search of better conditions and in an attempt to move nearer to their families. This makes the staffing situation in such schools to be dominated by female teachers. The gender disparity among respondents in this study was therefore a true reflection of the situation on the ground as such it was expected to aid to the validity of the findings. 


\subsection{Age of Respondents}

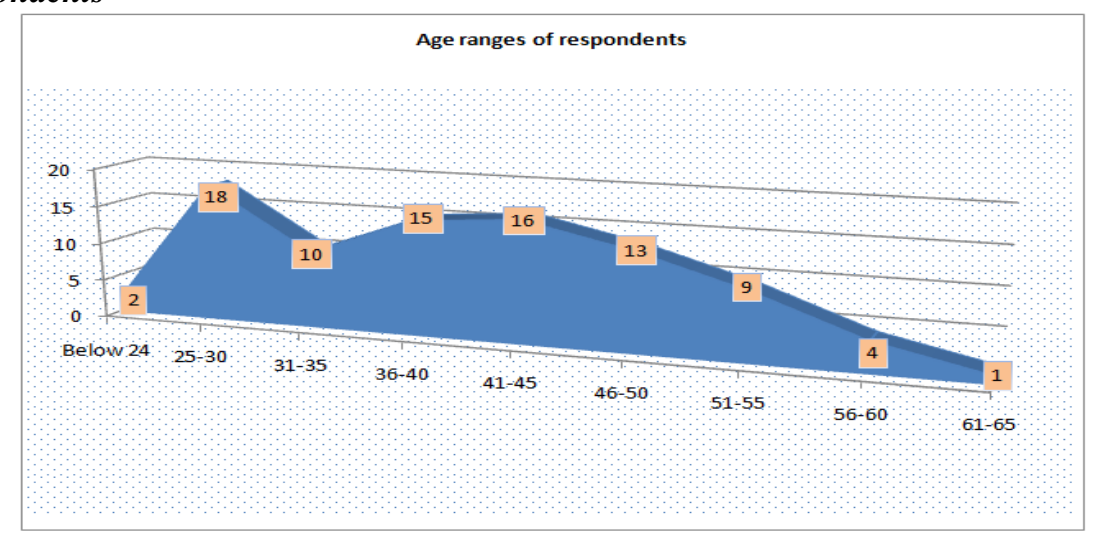

The respondents' ages as presented on the table above show that the age range of 25 to 30 years had the highest number among respondents with 18, while the 61 to 65 age range had the least with only 1 respondent falling in that category. The age range profile shows that teaching staff in Marondera District is middle aged. Such a staff is expected to be at the prime of their teaching career and are least expected to suffer from burnout.

\subsection{Length of service of respondents}

It is argued by most researchers among them Maslach and Jackson (1985) and Cordes and Dogherty (1997) that the length of time taken to do the same task or activity is closely associated with burnout. It is for that reason that the parameter of length of service became important in this study.

\begin{tabular}{|l|l|l|l|l|l|}
\hline & Length of service & Frequency & Percent & Valid Percent & Cumulative Percent \\
\hline \multirow{5}{*}{ Valid } & Less than 5 years & 21 & 23.9 & 23.9 & 23.9 \\
\cline { 2 - 6 } & $6-10$ & 8 & 9.1 & 9.1 & 33.0 \\
\cline { 2 - 6 } & $11-15$ & 13 & 14.8 & 14.8 & 47.7 \\
\cline { 2 - 5 } & $16-20$ & 17 & 19.3 & 19.3 & 67.0 \\
\cline { 2 - 5 } & More than 20 & 29 & 33.0 & 33.0 & 100.0 \\
\hline & Total & $\mathbf{8 8}$ & $\mathbf{1 0 0 . 0}$ & $\mathbf{1 0 0 . 0}$ & \\
\hline
\end{tabular}

The length of service for the 88 respondents varies with most having served for more than 5 years. Those with more than 20 years' experience constituted $33 \%$ of the total respondents while those who served for less than 5 years were the least constituting 24\%. Respondents with 6 to 10 years of teaching experience made up 9\%. This shows that in Marondera District, $76 \%$ of the teachers have more than 5 years' experience and such teachers are quite senior. They are expected to have accumulated practical skills, techniques and strategies which help them enjoy their work.

\subsection{Respondents' qualifications}

\begin{tabular}{|l|l|l|l|l|l|}
\hline \multirow{3}{*}{ Valid } & Highest Qualification & Frequency & Percent & Valid Percent & Cumulative Percent \\
\cline { 2 - 6 } & Diploma/Certificate in Education & 20 & 22.7 & 22.7 & 22.7 \\
\cline { 2 - 6 } & Higher Diploma & 1 & 1.1 & 1.1 & 23.9 \\
\cline { 2 - 6 } & Bachelor's Degree & 62 & 70.5 & 70.5 & 94.3 \\
\cline { 2 - 6 } & Masters' Degree & 5 & 5.7 & 5.7 & 100 \\
\hline
\end{tabular}

From the data presented on the above table, analysis showed that the most frequent highest qualification possessed by secondary school teachers in Marondera District is the bachelor's degree with $70.2 \%$ of the respondents being holders of first degrees. It can be concluded with certainty that since the basic teaching qualification in Zimbabwe is a Diploma or Certificate in Education, secondary school teachers in Marondera District are highly qualified. When professionals are highly qualified, they are expected to have an array of skills and strategies of discharging work and such workers are least expected to suffer burnout. They are also expected to have many burnout prevention and coping techniques under their sleeves which they can fall back to in order to avoid burnout. The teachers who hold diplomas or certificates constitute $22.7 \%$ while those with master's degreesare a minority of $5.7 \%$.

\subsection{Respondents' marital status}

\begin{tabular}{|c|c|c|c|c|c|}
\hline \multicolumn{6}{|c|}{ Respondent's marital status } \\
\hline & & Frequency & Percent & Valid Percent & Cumulative Percent \\
\hline Valid & Single & 16 & 18.2 & 18.2 & 18.2 \\
\hline
\end{tabular}


An Investigation into the Problem of Human Capital Burnout in the Public Service of Zimbabwe:...

\begin{tabular}{|l|l|l|l|l|l|}
\hline & Married & 64 & 72.7 & 72.7 & 90.9 \\
\cline { 2 - 6 } & Divorced & 2 & 2.3 & 2.3 & 93.2 \\
\cline { 2 - 6 } & Separated & 2 & 2.3 & 2.3 & 95.5 \\
\cline { 2 - 6 } & Widowed & 4 & 4.5 & 4.5 & 100.0 \\
\cline { 2 - 6 } & Total & 88 & 100.0 & 100.0 & \\
\hline
\end{tabular}

Married respondents in this study constituted the highest percentage of $72.7 \%$, followed by single respondents who constituted $18.2 \%$.The lowest frequencies in the marital status parameter were the separated respondents who made up 2.3\%.Marriage roles which include parenthoodare known to exert more pressure and responsibilities on employees especially the females.

\subsection{Investigating the prevalence of burnout among secondary school teachers}

One of the objectives of this study was to investigate the prevalence of burnout among secondary school teachers and one way analysis of variance was used to compute the responses. The one way analysis of variance (ANOVA) is used to determine whether there is any significance difference between the means of two or more independent or unrelated groups. Specifically ANOVA tests the null hypothesis. The F and the $\mathrm{P}$ values are used and if $\mathrm{P}<0.05$ then $\mathrm{H}_{0}$ is rejected. If the $\mathrm{F}$ value is close to 1.0 then the null hypotheses is true most of the time.

\begin{tabular}{|l|l|l|}
\hline Descriptive Statistics on burnout factors & Mean & Standard Deviation \\
\hline Burnout Factor & & \\
\hline I feel emotionally drained by my work & 2.86 & 2.03 \\
\hline Working with students all day long requires a great deal of effort & 4.89 & 1.77 \\
\hline I feel like my work is breaking me down & 1.86 & 2.05 \\
\hline I feel frustrated by work & 2.10 & 2.01 \\
\hline I feel I work hard at my work & 3.64 & 2.32 \\
\hline It stresses too much when I am in direct contact with students & 1.38 & 1.90 \\
\hline I feel tired and I dread to wake up every morning to face another day. & 2.10 & 1.89 \\
\hline I really do not care about what happens to my students. & 0.39 & 0.96 \\
\hline $\begin{array}{l}\text { I have become more insensitive to my students over the years since I } \\
\text { joined teaching }\end{array}$ & 0.68 & 1.30 \\
\hline I am afraid that this job is making me uncaring & 0.59 & 1.44 \\
\hline
\end{tabular}

\begin{tabular}{|l|l|}
\hline Descriptive Statistics & \\
\hline Minimum Burnout score & 0.2 \\
\hline Maximum Burnout score & 4.9 \\
\hline Mean Burnout score & 2.0398 \\
\hline Standard Deviation & 1.11216 \\
\hline
\end{tabular}

There was need to test the hypothesis: Gender is associated with burnout among secondary school teachers. This follows the assumption that female teachers succumb faster to burnout as compared to their male counterparts owing to the fact that while males engage in sports and patronise recreational centres after work, females being mothers have to do household chores and look after the children after work in line with African culture. This gives female teachers little or no time to rest giving rise to burnout. This hypothesis was tested using the one way analysis of variance by gender.

\begin{tabular}{|c|c|c|c|c|c|}
\hline \multicolumn{6}{|l|}{ One way Anova by gender } \\
\hline Burnout Factor & $\begin{array}{l}\text { Male } \\
\text { Mean }\end{array}$ & $\begin{array}{l}\text { Female } \\
\text { Mean }\end{array}$ & $\begin{array}{l}\text { F- } \\
\text { statistic }\end{array}$ & $\begin{array}{l}\text { p- } \\
\text { value }\end{array}$ & Decision rule \\
\hline I feel emotionally drained by my work & 3.00 & 3.00 & 0.017 & 0.896 & $\begin{array}{l}\text { Accept } \mathrm{H}_{0} \text { and conclude that } \\
\text { there is no significant difference } \\
\text { between the means of male } \\
\text { respondents and that of females }\end{array}$ \\
\hline $\begin{array}{l}\text { Working with students all day long requires a great } \\
\text { deal of effort }\end{array}$ & 5.00 & 5.00 & 0.035 & 0.852 & Accept $\mathrm{H}_{0}$ \\
\hline I feel like my work is breaking me down & 1.90 & 1.80 & 0.344 & 0.559 & Accept $\mathrm{H}_{0}$ \\
\hline I feel frustrated by work & 2.00 & 2.00 & 5.704 & 0.019 & Reject $\mathrm{H}_{0}$ \\
\hline I feel I work hard at my work & 4.00 & 3.00 & 0.453 & 0.503 & Accept $\mathrm{H}_{0}$ \\
\hline $\begin{array}{l}\text { It stresses too much when I am in direct contact } \\
\text { with students }\end{array}$ & 2.00 & 1.00 & 0.77 & 0.383 & Accept $\mathrm{H}_{0}$ \\
\hline $\begin{array}{l}\text { I feel tired and I dread to wake up every morning to } \\
\text { face another day. }\end{array}$ & 2.00 & 2.00 & 0.322 & 0.572 & Accept $\mathrm{H}_{0}$ \\
\hline $\begin{array}{l}\text { I really do not care about what happens to my } \\
\text { students. }\end{array}$ & 0.00 & 0.00 & 3.403 & 0.069 & Reject $\mathrm{H}_{0}$ \\
\hline $\begin{array}{l}\text { I have become more insensitive to my students } \\
\text { over the years since I joined teaching }\end{array}$ & 0.00 & 0.00 & 3.401 & 0.307 & Accept $\mathrm{H}_{0}$ \\
\hline I am afraid that this job is making me uncaring & 0.00 & 1.00 & 1.028 & 0.313 & Accept $\mathrm{H}_{0}$ \\
\hline
\end{tabular}


This is illustrated in the table of one way ANOVA by gender where the item "I am afraid that this job is making me uncaring" where the $\mathrm{F}$ value is 1.028 the $\mathrm{P}$ value in this instance is 0.313 and we accept the hypothesis.

After computations, the $\mathrm{H}_{0}$ is accepted that there is no significant difference between males and females as regards many burnout factors except the construct of 'I feel frustrated at work' and 'I really do not care about what happens to my students'. After an analysis of the outcome using the SPSS frequency it was concluded that while there is no significant differences between males and females, poor motivation indeed influence burnout among teachers. The study by Adekola (2009) contradicts the findings as it alluded that women are better equipped for human relations and sharing their negative emotions while men suppress their emotional impulses in order to live up to their roles and this making them inclined to have cynical attitudes as a means of coping with stress.

Using Anova, there was also a need to test if burnout among secondary school teachers was associated with their marital status.

\subsection{Prevalence of burnout}

\begin{tabular}{|c|c|c|c|c|c|}
\hline \multicolumn{6}{|l|}{ One way Anova by marital status } \\
\hline Burnout Factor & $\begin{array}{l}\text { Married } \\
\text { Mean }\end{array}$ & $\begin{array}{l}\text { Single } \\
\text { Mean }\end{array}$ & $\begin{array}{l}\text { F- } \\
\text { statistic }\end{array}$ & $\begin{array}{l}\text { p- } \\
\text { value }\end{array}$ & Decision rule \\
\hline $\begin{array}{l}\text { I feel emotionally drained by my } \\
\text { work }\end{array}$ & 3.50 & 2.80 & 0.864 & 0.355 & $\begin{array}{l}\text { Accept } \mathrm{H}_{0} \text { and conclude that there is no } \\
\text { significant difference between the } \\
\text { means of married males and single } \\
\text { respondents }\end{array}$ \\
\hline $\begin{array}{l}\text { Working with students all day } \\
\text { long requires a great deal of } \\
\text { effort }\end{array}$ & 3.88 & 4.99 & 2.934 & 0.09 & $\begin{array}{l}\text { Accept } \mathrm{H}_{0} \text { and conclude that there is no } \\
\text { significant difference between the } \\
\text { means of married males and single } \\
\text { respondents }\end{array}$ \\
\hline $\begin{array}{l}\text { I feel like my work is breaking } \\
\text { me down }\end{array}$ & 2.13 & 1.84 & 0.142 & 0.707 & $\begin{array}{l}\text { Reject } \mathrm{H}_{0} \text { and conclude that there is } \\
\text { significant difference between the } \\
\text { means of married males and single } \\
\text { respondents }\end{array}$ \\
\hline I feel frustrated by work & 2.63 & 2.05 & 0.595 & 0.74 & $\begin{array}{l}\text { Accept } \mathrm{H}_{0} \text { and conclude that there is no } \\
\text { significant difference between the mean } \\
\text { of married males and single respondents }\end{array}$ \\
\hline I feel I work hard at my work & 3.38 & 3.66 & 0.111 & 0.443 & $\begin{array}{l}\text { Accept } \mathrm{H}_{0} \text { and conclude that there is no } \\
\text { significant difference between the } \\
\text { means of married males and single } \\
\text { respondents }\end{array}$ \\
\hline $\begin{array}{l}\text { It stresses too much when I am in } \\
\text { direct contact with students }\end{array}$ & 2.13 & 1.30 & 1.384 & 0.243 & $\begin{array}{l}\text { Accept } \mathrm{H}_{0} \text { and conclude that there is no } \\
\text { significant difference between the } \\
\text { means of married males and single } \\
\text { respondents }\end{array}$ \\
\hline $\begin{array}{l}\text { I feel tired and I dread to wake } \\
\text { up every morning to face another } \\
\text { day. }\end{array}$ & 2.75 & 1.94 & 1.357 & 0.247 & $\begin{array}{l}\text { Accept } \mathrm{H}_{0} \text { and conclude that there is no } \\
\text { significant difference between the } \\
\text { means of married males and single } \\
\text { respondents }\end{array}$ \\
\hline $\begin{array}{l}\text { I really do not care about what } \\
\text { happens to my students. }\end{array}$ & 0.38 & 0.39 & 0.001 & 0.972 & $\begin{array}{l}\text { Accept } \mathrm{H}_{0} \text { that there is no significant } \\
\text { difference between the mean of married } \\
\text { males and single respondents }\end{array}$ \\
\hline $\begin{array}{l}\text { I have become more insensitive } \\
\text { to my students over the years } \\
\text { since I joined teaching }\end{array}$ & 0.75 & 0.68 & 0.024 & 0.877 & $\begin{array}{l}\text { Accept } \mathrm{H}_{0} \text { and conclude that there is no } \\
\text { significant difference between the } \\
\text { means of married males and single } \\
\text { respondents }\end{array}$ \\
\hline $\begin{array}{l}\text { I am afraid that this job is } \\
\text { making me uncaring }\end{array}$ & 1.00 & 0.55 & 0.712 & 0.401 & $\begin{array}{l}\text { Accept } \mathrm{H}_{0} \text { and conclude that there is no } \\
\text { significant difference between the } \\
\text { means of married males and single } \\
\text { respondents }\end{array}$ \\
\hline
\end{tabular}

The table summarizes the relationship between the means by marital status of therespondents in respect to the burnout variables as derived from the MBI Questionnaire.From the results that are in the decision column, it was observed that from the provided variables that there was no significant difference in the means except for the variable 'I feel like my work is breaking me down'. This shows that both single and married teachers experience burnout in their workplaces in Marondera District.

4.9 Assessing the motivation techniques used on staff in secondary schools. 


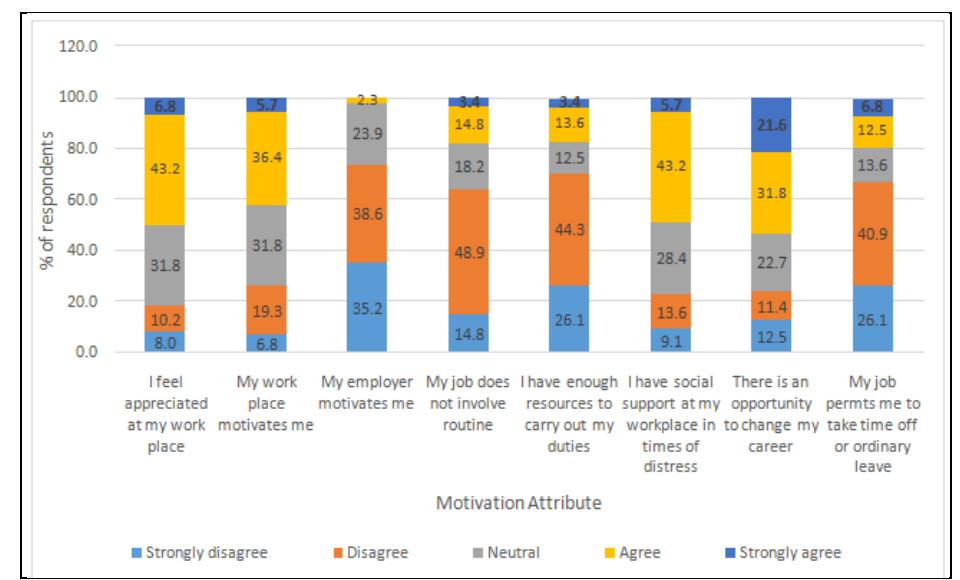

The graph illustrates the rating of the levels of motivation experienced by teachers in Marondera District. The findings point to three key motivation areas where respondents show dissatisfaction, which all involve the role of the employer. The analysis shows that a total of $73.8 \%$ disagreedand strongly disagreedthat the employer (Government through Public Service Commission) motivates them as shown by responses to the

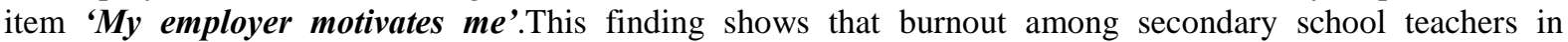
Marondera District could be emanating from the employer's failure to motivate staff. This finding also tallies with the findings from the qualitative responses which showed that teachers want issues of remuneration and other rewards to be addressed and this was given as critical area in the rankings provided according to the demands of the question asked on motivation. Sunbul (2003) carried out a study in Turkey and concluded that the employer had a duty to address the increasing job demands and employee dissatisfaction to improve the well-being of teachers.

The other burning issue driving burnout is the issue of shortage of resources. Respondents showed that shortage of resources demotivated them as shown by $70.4 \%$ being the sum of those who indicated under strongly disagree and disagree to the item 'I have enough resources to carry out my duties'. When employees lack adequate resources to carry out their work, it does not matter how resourceful or creative they can be, performance is bound to be negatively affected. A study by Sari (2000) found out that high emotional exhaustion is experienced when teachers are not given enough resources. Teachers do not want to be embarrassed in front of their students when they discover that they do not have the resources to teach a particular lesson.Government, responsible authorities and parents have a duty to ensure that schools are well resourced to make the work of teachers easier and more exciting. If that is done, it will reduce the prevalence of burnout.

Motivation techniques preferred by secondary school teachers in Marondera District at the time of this study were: Appreciating their work $(50 \%)$, Giving social support at the workplace during times of distress $(48.9 \%)$ and being accorded opportunity to change career $(53.4 \%)$.

\subsection{Multi-skilling strategies employed in secondary schools}

\begin{tabular}{|l|l|l|}
\hline & My job involves routine & I am given an opportunity to multi-skill in my job \\
\hline Strongly disagree & 0.8 & 13.1 \\
\hline Disagree & 14.7 & 30.5 \\
\hline Neutral & 18.2 & 29.5 \\
\hline Agree & 48.9 & 21.8 \\
\hline Strongly agree & 17.4 & 5.1 \\
\hline
\end{tabular}

The findings show that teaching in Marondera District involves routine. According to the table, $17.4 \%$ of the respondents strongly agreed that their job is full of routine, $48.9 \%$ of the respondents agreed that the job has routine making a total of $66.3 \%$. From this finding, it can be concluded with reasonable certainty that the burnout phenomenon experienced by MaronderaDistrict teachers is partly driven by work routine. This is supported by the responses in the open-ended section. Respondents indicated that they carry out the same duties to the extent where they teach the same material year after year. This makes the job boring and less challenging. Newspaper reports also support this assertion when they state that some school syllabi had not been revised since attaining independence in 1980. This results in teachers teaching the same content and teaching in the way they were taught during their school days. Lunenburg (2011) supported the view that there was need to change organisational tactics so that burnout as caused by routine is reduced.

Respondents disagreed that their work involves multi skilling as evidenced by a total of $43.6 \%$ who strongly disagreed and disagreed while a total of $26.9 \%$ agreed that they are accorded opportunities for multiskilling. A high number of $29.5 \%$ remained neutral. If employees are not accorded multi-skilling opportunities, 
it means that they would continue doing the same job in the same role until they retire and that may drive burnout.

\subsection{Work load and Conditions of service}

\begin{tabular}{|l|l|l|l|l|l|}
\hline & Duration of frustration & Frequency & Percent & $\begin{array}{l}\text { Valid } \\
\text { Percent }\end{array}$ & $\begin{array}{l}\text { Cumulative } \\
\text { Percent }\end{array}$ \\
\hline Working with students all day & & & & & \\
\multirow{2}{*}{$\begin{array}{l}\text { long requires a great deal of } \\
\text { effort. }\end{array}$} & Never & 1 & 1.1 & 1.1 & 1.1 \\
\cline { 2 - 6 } & A few times per year & 8 & 9.1 & 9.1 & 10.2 \\
\cline { 2 - 7 } & Once per month. & 3 & 3.4 & 3.4 & 13.6 \\
\cline { 2 - 7 } & Few times per month & 9 & 10.2 & 10.2 & 23.8 \\
\cline { 2 - 7 } & Few per week & 11 & 12.6 & 12.6 & 36.4 \\
\cline { 2 - 7 } & Everyday & 56 & 63.6 & 63.6 & \\
\hline & Total & $\mathbf{8 8}$ & $\mathbf{1 0 0}$ & $\mathbf{1 0 0}$ & \\
\end{tabular}

The responses to the item on the table above shows that teachers had concerns over the demands of the work. This is shown by 56 out of 88 respondents $(63.6 \%)$ who agreed that every day they have to put effort in dealing with students. According to Maslach (1986) students have diverse personalities and the teacher has to deal with each one of them making the job too demanding.In this study, teachers reported that huge classes of more than 50 students of mixed ability with most ranging around average to below average in performance; this makes the teacher's workload phenomenal. The respondents wrote that the workloads needed to be reviewed downwards. Unfortunately, it came out during interviews with school heads that teachers feared that the new curriculum to be introduced with effect from 2017 was likely to bring even more work load making the burnout situation worse. Teachers are disgruntled that instead of increasing salaries, their employer increases workloads to unbearable levels.

\subsection{Conditions of service}

\begin{tabular}{|l|l|l|l|l|l|}
\hline & Strongly disagree & Disagree & Neutral & Agree & Strongly agree \\
\hline I feel appreciated at my work place & 29.3 & 24.2 & 21.8 & 13.2 & 11.5 \\
\hline
\end{tabular}

Findings to the closed item "I feel appreciated at my work place" show that $53.5 \%$ of the respondents felt unwanted at their workplaces, $24.7 \%$ felt appreciated while a significant number of $21.8 \%$ remained neutral. Teachers who feel unwanted may develop burnout as it is stressful to work hard for management and employers who do not appreciate one's work. From the qualitative responses, the respondents who felt unappreciated at their workplacesstated that their immediate supervisors were unfriendly, dictatorial and rigid. The drivers of motivation among teachers were identified as job control, access to information, supervisory support and a school climate which is conducive to innovation. Hanaken et al. (2005) andTariset al (2001) support the notion that employees desire to be appreciated and they require an open climate which allows for creativity.

\subsection{Relationship between marital status and burnout}

There was need to do cross tabulation to see if there is a relationship between marital status and burnout.

Respondent's cross tabulation on marital status

\begin{tabular}{|l|l|l|l|l|l|l|l|}
\hline & \multicolumn{9}{|l|}{ Respondent's marital status } \\
\hline & Duration of frustration & Single & Married & Divorce & Separated & Widowed & Total \\
\hline \multirow{3}{*}{$\begin{array}{l}\text { I fustrated } \\
\text { work. }\end{array}$} & Never & 10 & 16 & 0 & 1 & 0 & 20 \\
\cline { 2 - 9 } & A few times per year & 3 & 21 & 2 & 0 & 1 & 30 \\
\cline { 2 - 9 } & Once per month. & 1 & 5 & 0 & 0 & 0 & 6 \\
\cline { 2 - 9 } & Few times per month & 1 & 7 & 0 & 0 & 2 & 12 \\
\cline { 2 - 8 } & Few per week & 1 & 10 & 0 & 0 & 0 & 13 \\
\cline { 2 - 8 } & Everyday & 0 & 5 & 0 & 1 & $\mathbf{4}$ & 7 \\
\hline
\end{tabular}

From the analysis using SPSS cross tabulation, a snap view shown on the table indicates that 10 out of $16(62.5 \%)$ of the single teachers did not experience burnout linked to the variable of frustration at work while 16 out of $64(25 \%)$ of the married respondents stated that they never experienced burnout. The married respondents who experienced burnout linked to work conditions were 48 out of 64 constituting $75 \%$ as compared to only $37.5 \%$ of the single teachers. It can be concluded that burnout is associated with marital status with more married teachers being vulnerable and prone to burnout. This finding concurs with findings of studies by Ersan, Doga and Dogman (2011) and Maslach and Jackson (1985) on the relationship between marital status and burnout which concluded that there is a significant relationship between the two with married employees showing more burnout symptoms than single ones. 


\subsection{Coping strategies and stress management}



The findings from the above graph show that secondary school teachers in MaronderaDistrictemploy several coping strategies. The coping strategies range from $83 \%$ sporting, $48.9 \%$ social support and59.1\% going out to relax. However, $67 \%$ of the respondents disagreed to the item that "My job permits me to take time off or ordinary leave to relax and take a rest." Mental and emotional exhaustion as well as fatigue will result if workers are not accorded leave to rest.Such teachers are not expected to give their best. Zimbabwe's Labour Act, Chapter 28:01 singles out refusal to accord vacation leave to employees as an unfair labour practice committed by employers. Faber (1993) noted that if coping strategies are absent, workers are bound to encounter burnout.

\subsection{MBI questionnaire data analysis}

The MaslachBurnout Inventory (MBI) measures three categories of the burnout phenomenon in human capital linked services: Emotional exhaustion,Depersonalisation measures and burnout linked to Personal accomplishment using the low, moderate and high scale (Maslach, Jackson and Lieter, 2009). A total score of 17 or less is the low burnout, 18 to 29 is moderate burnout while a total of 30 and above is high burnout.

\subsection{Emotional Exhaustion Burnout}

According to Sunbul (2003) the emotional exhaustion category consists of 9 items that describe feelings of being emotionally overextended and exhausted by one's work. The sum of the responses on the nine items were illustrated in on the graph below:

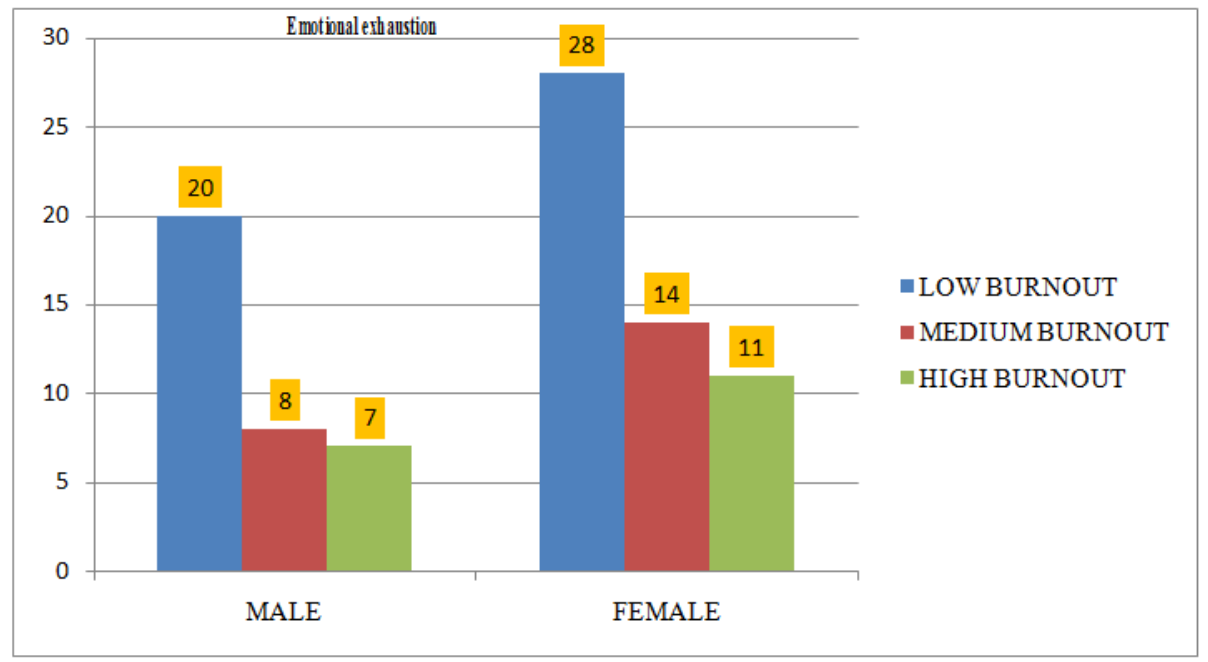

The above graph shows that 15 out of 35 male (42.9\%) and 25 out of 53(47.2\%) female secondary school teachers in Marondera District suffer from the emotional exhaustion in the range of medium to high burnout. If a significant total of 40 out 88 teachers (45.5\%) suffer from emotional exhaustion burnout, such a statistic spells doom to the students who are under the care of such teachers. This is made worse by the findings of Vandenberge, Roland, Huberman and Michael(1999) who found out that employees suffer from burnout unknowingly. Considering the key role played by teachers in shaping the future of the nation, $45.5 \%$ is a significant number notwithstanding that a total of 54.5\% suffer from low burnout. Another fact that came out from the analysis of the above findings is that female secondary school teachers tend to suffer more emotional 
exhaustion than their male counterparts. Such findings need to be attended to in order to assist the female teachers. This study noted that most female teachers making up the sample are married. According to African culture, they have to cook, feed the family, look after the children and carry out other household chores before and after work. These energy supping activities are bound to stretch and emotionally drain the female teachersgiving rise to the build-up of emotional exhaustion. However, the findings contradict a study carried out in Spain which showed that teachersin that country are driven into joining the profession as a calling and out of compassion, and the desire to serve and make a difference in the lives of people. If employees join a profession out of passion, it is likely to control burnout as such teachers would feel invigorated in front of a class.

\subsection{Relationship between qualifications and burnout}

There was need in this study to find out if there was a correlation between burnout and the qualifications of teachers. The widely held view is that those who are highly qualified are least expected to suffer from burnout given their wide array of skills including knowledge of prevention and coping strategies.

Cross- Tabulation: Respondents qualifications * I feel frustrated at work



The cross-tabulationillustrates the level of burnout experienced by the teachers in Marondera District. Teachers who hold bachelor's degrees experience the highest burnout as illustrated above. Most teachers with Bachelor's degrees indicated that they are frustrated at work daily. It was not clear why such highly qualified individuals were frustrated, but in response to earlier questions, it was clear that there is little room for innovation in the teaching profession as most behaviour and activities are strictly regulated, time tabled and scheduled by policy documents. It is such an environment which could be frustrating graduate teachers.

\subsection{Burnout results on depersonalization/ cynicism}

Maslach (2006) defines depersonalization as a situation where a professional looks at a client without the passion to help. This has also been referred to as cynicism in the study of burnout among professionals. In other studies it is referred to as dehumanization. The employee or worker who experiences depersonalization withdraws oneself, has a feeling of guilt and avoids social contacts and empathy that is needed to be shown to colleagues or students. According to MBI, the scoring for this category is as follows: a total of 5 or less is low level burnout; 6 to 11 is moderate burnout while a total of 12 and above is high burnout. The results of the depersonalization burnout are shown on the table provided below with the results analysed according to the frequencies on gender.

\begin{tabular}{|l|l|l|l|l|}
\hline Depersonalisation burnout & Low burnout & Moderate Burnout & High Burnout & Total \\
\hline Male & 13 & 13 & 9 & 35 \\
\hline Female & 25 & 16 & 12 & 53 \\
\hline Total & $\mathbf{3 8}$ & $\mathbf{2 9}$ & $\mathbf{2 1}$ & $\mathbf{8 8}$ \\
\hline
\end{tabular}


The findings show that at total of $56.8 \%$ of secondary school teachers in Marondera District experience depersonalisation burnout in the moderate to high categories. Such a figure is too high for professionals who hold key positions of shaping the country's youths. No country can allow a situation where $56.8 \%$ of their critical workforce continues working when they have such high levels of depersonalisation. While the other $43.2 \% \%$ suffer from low burnout, such figure is too low for the teachers to pass the fitness-for-purpose test.Teachers are expected to infuse and infect their students with enthusiasm, creativity, innovation to confront and provide solutions to the problems they meet in life, but if only $43.2 \%$ have low burnout, very little can come out of it. With reference to studies carried out on depersonalization burnout, Jackson, Lieter and Maslach (2006) found out that professionals are sometimes overwhelmed and become detached from their clients due to burnout.

\subsection{MBI Personal Achievement Results}

Personal achievement is also referred to as personal accomplishment(Maslach and Schaufeli, 2006).It measures feelings of competence and successful achievement in one's work. It focuses on the reduction of personal achievement when the individual assesses himself/ herself negatively and feels not capable to move the situation forward. According to Maslach and Schaufeli (2006) this component gives the effects of too much routine in a workplace where the person begins to doubt their abilities to achieve things. This subscale is a result of emotional exhaustion and depersonalization. The scoring results are: 33 or less in the low burnout, 34 to 39 is in the moderate burnout while 40 and above is high burnout. The personal accomplishment consists of eight items describing the competence and successes about one's achievements.

\section{Personal Achievement \\ Self-achievement}

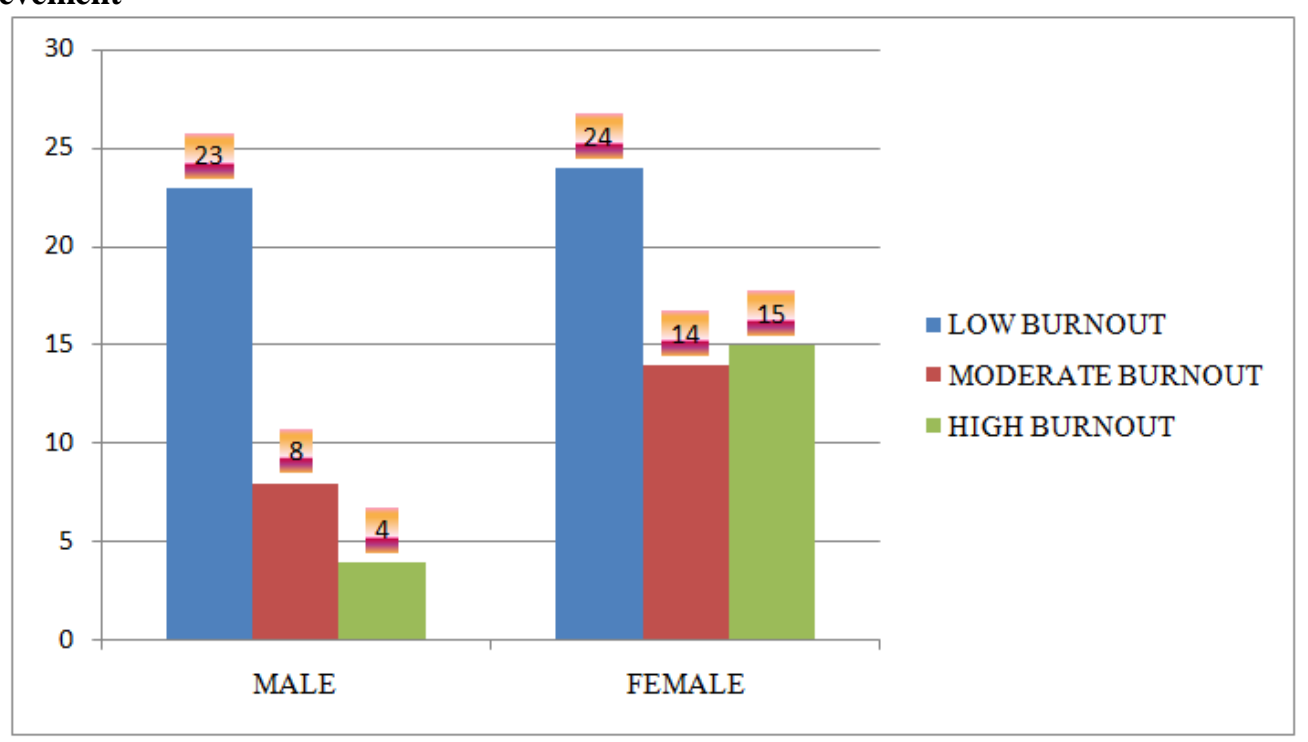

According to the graph above, a total of 41 (46.6\%) male and female secondary school teachers in Marondera District are affected by lack of personal achievement with moderate to high burnout levels. Such findings indicate that the teachers have low self-esteem and are demoralised. They are unlikely to motivate students if they themselves are demotivated. Authorities in education, among them Jean Piaget (1978) state that a normal student does not want to learn and it is the task of every teacher to motivate the students so as to create readiness and a desire to learn; but it is only motivated teachers who can motivate students. Motivated teachers have personal achievement as one of their attributes. Further analysis of the findings on the above graph shows that more female teachers than males suffer from lack of personal achievement.

Studies carried out in Turkish high schools found out that personal accomplishment was strongly related to age.Findings byMaslach (1982) and Brunetti (2001) and studies done on Turkish teachers Sunbul (2003) indicated that the levels of personal accomplishment in male and female teachers are fairly similar. The differences in gender roles, gender stereotypes and cultural or societal expectations could be responsible for the differences in the levels of self-accomplishment among female and male teachers. The same phenomenon was brought out in the interviews where the key informants expressed that the females fail to reach their full potential because they have responsibilities in and out of workplaces that hinder them from achieving their best in their profession. 


\subsection{Qualitative Analysis}

The last part of the questionnaire comprised questions that were qualitative in nature where the respondents were supposed to express areas related to the nature of burnout in their profession. In response to a question on the things that make them dislike their job as teachers, responses ranged from a minimum of four things to a maximum of eight per respondent. The following were frequently mentioned: Poor salaries, poor reward system, lack of resources, lack of support from the employer, lack of appreciation for hard work, poor promotion prospects, work overload, poor leadership from school heads and lack of recognition.

Five heads of schools were interviewed and an interview guide with four open ended questions was administered. The School Heads pointed out that some of the signs of burnout among teachers were poor performance, general fatigue, poor results from students, absenteeism and aggression by some teachers in general meetings. Not meeting deadlines in submission of documents and failure to fulfil duties as stipulated in policy documents, extreme tiredness, hostility and isolating one from students and workmates were also mentioned. The school heads also pointed out that some teachers have expressed having trouble in getting enough rest and sleep; a thing which points to the existence of insomnia among some teachers.

Another Head expressed that burnout in teachers is caused by lack of appreciation of the teacher by the employer in terms of low salaries, a thing which led to low morale. In addition, the head mentioned paperwork overload as one of the causes of teacher burnout. Examples were given where teachers carried exercise books to be marked at home after work instead of resting.

\section{Conclusions}

Based on the findings, the following conclusions were arrived at:

- The burnout phenomenon among secondary school teachers manifests in the form of emotional exhaustion, lack of zeal to work hard, depression, depersonalization, lack of enthusiasm, general tiredness, lack of innovation and creativity, 'I don't care' attitude and general fatigue.

- A significant number of teachers in high schools experienced burnout in the moderate and high categories.

- The study showed that burnout exists among teachers regardless their gender.

- The findings of the study point to the fact that the proportion of females affected by burnout is higher than that of the males.

- Burnout at work places is associated with the productive and reproductive gender roles of the affected individuals such as responsibilities to nurture the family and balancing that with the demands of the work place.

- Female staff experienced higher levels of reduced personal accomplishments, emotional exhaustion and depersonalisation than their male counterparts.

- The existence of burnout was linked to the socio demographic factors such as age, gender, marital status, academic qualification and length of service by the teacher.

- The findings from this research were that multi-skilling techniques are minimal in the teaching profession. Respondents expressed that they had stress and had developed frustration because of routine which characterises their work on a daily basis.

- It was the finding of this study that teachers had heavy workloads in and outside the actual teaching experience. They have large classes;they monitor discipline, supervise work, supervise sports, carryout remedial work and keep the general environment they operate in clean. Teachers play the roles of examiners,administrators,instructors,counsellors, disciplinarians and put in place strategies that assist the students to pass. Teachers felt overwhelmed, drained and exhausted leading to burnout.

- The coping mechanisms used by teachers such as sports andsocialising after work were inadequate to curb burnout.

\subsection{Recommendations to Teachers and Authority}

\section{Recommendations}

Based on the findings and conclusions of this study, the following recommendations were proffered:

6.1. Authorities should put in place strategies to avoid the development of burnout among teachers. Such strategies may include but not limited to: provision of adequate teaching and learning resources, multiskilling opportunities, advancement opportunities, use of ICTs (Information and Communication Technologies) in teaching and learning to make the work easier and more exciting, generous leave conditions, recreational facilities, deploying teachers to work near their families, appropriate accommodation with electricity and commensurate salaries.

6.2. Educational managers and leaders should be trained to use appropriate leadership styles which inspire and motivate teachers to perform at their best. Good leadership should make teachers feel appreciated and should inspire them to work hard happily in a manner which makes work as exciting as play. 
6.3. Teachers should be trained appropriate burnout prevention, coping and management strategies. Living a happy lifestyles, well managed family and love life, sports/ games, excursions, and other recreational or leisure activities should be encouraged.

6.4. Educational managers and leaders should be skilled team-builders who have the ability to make teachers happy and enthusiastic in their performance as the adage goes, 'You cannot have hardworking employees unless they are happy employees'. This follows the finding that unskilled leaders are the major drivers of burnout among teachers. They cause unnecessary stress to build-up making teachers hate their job and this drives burnout.

6.5. Communities and other stakeholders should be taught to appreciate the work teachers do. The teaching profession should be the most respected, ahead of doctors or lawyers because of its sacrosanct role in shaping the minds of youths and ultimately the nation at large.

6.6. Based on the gravity of the burnout phenomenon discussed in this study, it is recommended that burnout management strategies be seriously considered as a topic during the training of teachers in colleges, during in-service or staff development workshops of teachers and heads of schools.

\subsection{Recommendations to policy}

Human capital burnout is a serious threat to national development and to the development of any organisation as it can affect the achievement of strategic goals. It is recommended that policies on burnout management, monitoring and coping should be promulgated to help managers and leaders. The government as the biggest employer through the Public Service Commission should take the lead in abiding by such a policy

\subsection{Recommendation forfurther studies}

The study concentrated on burnout among teachers in secondary schools in Marondera District. If the research is replicated to primary school teachers and other civil service sectors, the findings could make interesting comparison.

[1]. Adekola, B. (2010). Gender Difference and the Experience of Work Burnout among University Staff. African Journal of Business Management, Vol.4 (6), p. 886-889

[2]. Babbie, E. R. (2012). The Practice of Social Research. Wadsworth Belmont, California

[3]. Beehr, T. A. (2014) Psychological Stress in Workplaces. Psychological Reviews.Routledge.

[4]. Bakker, A. B., Demerouti, E., and Euwema, M. C. (2005). Job Resources Buffer the Impact of Job Demands on Burnout. Journal of Occupational Health Psychology, Vol. 10(2).p. 170-180.

[5]. Bell, E. and Brymann, A. (2003) Business Research Methods, Oxford University Press, USA.

[6]. Brunetti, G. J. (2001). Why Do They Teach? A Study of Job Satisfaction Among Long-term High School Teachers. Teacher Education Quarterly, Vol. 28(3), p49-74.

[7]. Bryman,A. (2011). Social Research Methods. $3^{\text {rd }}$ Edition. Oxford University Press

[8]. Cooper, D. R. and Schindler, P. S. (2006). Business Research Methods. McGraw Hill, Irwin.

[9]. Cordes, C. L. , Dougherty, T. W. and Blum, M.(1997). Patterns of Burnout among Managers and Professionals. A Comparison of Models. Journal of Organisational Behaviour. Vol. 18, p. 685-701.

[10]. Demerouti, E. and Bakker, A. B. (2007).The Measurement of Burnout and Engagement. Netherlands Department of Work and Organizational Psychology. Erasmus University Rotterdam.

[11]. Demerouti, R., Bakker, A. B., Vardakou I., and Kanters, A. (2003). The Convergent Validity of the Two Burnout Instruments Multi-Trait Method Analysis. European Journal of Psychological assessment. Vol. 19(1) p.12-23.

[12]. Ferreira, A.I. and Martinez, L. F. (2012). Presenteeism and Burnout in Public and Private Portuguese Elementary Schools. International Journal of Human Resource Management, Vol.23, No 20.

[13]. Flett. G. L. and Hewitt, P. L. (2005). The Perils of Perfection in Sports and Exercise. Curriculum Dire Psychological Science. Vol 14(1) p. $14-18$

[14]. Green, G (1960). A Burnout Case. London: Heinemann.

[15]. Lewis, R. (1997) The Discipline Dilemma. Melbourne. Acer Press

[16]. Leiter, P. M. and Maslach, C. (2001). Job Burnout. Annual Reviews Psychological Journal. Volume 52 p. $397-422$

[17]. Lieter, M. P., Bakker, A. B. and Maslach, C. (2014). Burnout at Work: A Psychological Perspective. Hove Psychological Press.

[18]. Lunenburg, F, C. (2011). Motivating by Enriching Jobs to make them more Interesting and Challenging. International Journal of Management, Business and Administration, Vol 15 No. 1, 2011.

[19]. Maslach, C. and Jackson, S. E. and Leiter. M. P.(1986) Maslach Inventory OutcomesDatabase.org

[20]. Maslach.C. and Leiter, M.P.(2005). Stress and Burnout: Handbook of Stress Medicine and Health. $2^{\text {nd }}$ (ed) p.153-170. Boca Raton FL; CRC Press LLC

[21]. Maslach, C. (1996) Job Burnout. Journal of Applied Psychology, Vol 93(3), p. 498-512.

[22]. Maslach, C. and Leiter M. (2008) Early Predictors of Job Burnout. Journal of Applied Psychology, 93(3), p. 498-512.

[23]. Maslach, C. Leiter, M. P. and Schaufeli,B.(2009). Burnout: 35 Years of Research and Practice. Career Development International Journal, Vol. 14 No 3, p.202-220.

[24]. Maslach, C. (1982). Understanding Burnout: Definitional Issues in Analysing a Complex Phenomenon. (p.29-40) Beverly Hills. CA Sage.

[25]. Maslach, C., Schaufeli, W. B. and Leiter, M. P.(2001). Job Burnout.Annual Review Psychology. Vol 52 p.397-422.

[26]. Schaufeli, W. B.(2003). Past Performance and Future Perspectives of Burnout Research. S.A Journal of Industrial Psychology, 29(4),p. 1-15 Netherlands

[27]. Schaufeli, W. B. (2009). How Changes in Job Demand and Resources Predict Burnout Work, Engagement and Sickness Absenteeism. Journal of Organisational Behaviour, $\mathrm{Vol}$ 30(7), P. 893-917. 
[28]. Sichambo, M. N., Maragia, and S.M. Simiyu, A. M. (2012). Causes of Burnout among Secondary School Teachers: A Case of Bungoma North District. Kenya. International Journal of Academic Research in Progressive Education.Boca Raton FL; CRC Press LLC.

[29]. Smith, L. W., (2015). Commission, fatigue, Burnout and self -care: What social work students need to know? Paper (6)2015 Dissertation paper.

[30]. Smith, D., and Leng, G. W. (2003). The Prevalence and Sources of Burnout in Singapore Secondary School Physical Education Teachers. Journal of Teachers in Physical Education. Vol. 22, 203-218.

[31]. Taris, T. W., Shreurs, P. J. G., and Van Iersel-van Silfout, I. J. (2001). Job Strain and Psychological Withdrawal among Dutch. University Study. Work and Stress. Vol. 15 p. 183-296.

[32]. Saunders,M., Lewis,P. and Thornhill,A. (2009). Research Methods for Business Students. $5^{\text {th }}$ Edition. Pearson Education Limited. Essex

[33]. Schaufeli,W. and Enzmann, D. (1998).The Burnout Companion to Study and Practice:A Critical Analysis. Nottingham, UK. http://www.forbes.com/sites

http://www.surveysystem.com/sample-size-formula.htm

http://connectability.ca/Garage/wp

http://www.raosoft.com/samplesize.hthttp://www.researcher.euml

info@burnout.university 